\title{
Effect of Submerged and Floating Plants on Dissolved Oxygen Dynamics and Nitrogen Removal in Constructed Wetlands
}

\author{
B.G.N. Sewwandi, S.K. Weragoda ${ }^{1}$, M.I.M. Mowjood ${ }^{2}$ \\ N. Tanaka ${ }^{1}$ and S. Sasikala ${ }^{2}$ \\ Postgraduate Institute of Agriculture \\ University of Peradeniya \\ Peradeniya, Sri Lanka
}

\begin{abstract}
Dissolved oxygen (DO) concentration affects the treatment processes in constructed wetlands. This study examined the dissolved oxygen dynamics and total nitrogen removal in constructed wetlands with submerged and floating plants. Four constructed wetland units each with the surface area of $3 \times 1 \mathrm{~m}^{2}$ were constructed at University of Peradeniya. Two of those with the depths of $0.3 \mathrm{~m}(\mathrm{~A})$ and $0.6 \mathrm{~m}(\mathrm{~B})$ were planted separately with Hydrilla verticillata (submerged) and Lemna minor (floating), respectively. Other two $(C$ and $D)$ were constructed with two sections of 0.3 and $0.6 \mathrm{~m}$ depths and planted with $\underline{\mathrm{H}}$.

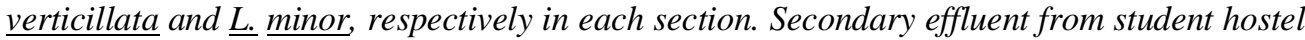
was fed with hydraulic retention time of 6 days. DO was measured at different depths of water, 0.0, 0.1, 0.2, 0.4 and $0.5 \mathrm{~m}$ from the water surface and along the longitudinal axis of the wetland at 6 hours interval. The total nitrogen was measured for water samples at inlet and outlets. The average dissolved oxygen concentrations of $A$ and $B$ were 17.7 and $0.4 \mathrm{mg}$ $L^{-1}$ respectively. Oxic condition was maintained in the submerged plant units. Anoxic condition resulted throughout the day in floating plant system. DO varied significantly with depths in oxic condition. DO dynamics in these wetlands can be explained by photosynthesis, respiration, deaeration and reaeration processes. The highest total nitrogen removal was achieved in unit $D$ where combined anoxic and oxic conditions were maintained together $H$.

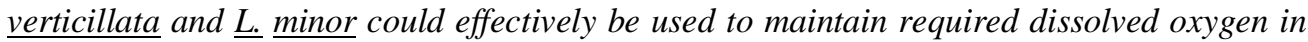
constructed wetlands for nitrate removal.
\end{abstract}

\section{INTRODUCTION}

Dissolved oxygen (DO) in water is essential for the biochemical processes which determine the fate of nitrogen and organic pollutants of wastewater in constructed wetlands (CWs) (Mowjood and Kasubuchi, 1998). Oxidative and reductive conditions can affect the transformation process of organic and inorganic substances in a submerged system. Oxygen can be transferred to wetlands with the influent water, from the atmosphere and via plant tissues into the water column (Mowjood and Kasubuchi, 2002; Tanner et al., 2002; Imfeld et al., 2009).

Submerged plants have been studied for different purposes such as uptake of pollutants (Ozimek et al., 1993; Kanabkaew and Puetpaiboon, 2004), competition between different submerged plant species (James et al., 1999), integration with microbes (Chang et al., 2006)

Graduate School of Science and Engineering, Saitama University, Japan

2 Department of Agricultural Engineering, Faculty of Agriculture, University of Peradeniya, Sri Lanka 
and enhancing microbial activities (Karjalainen et al., 2001). Floating plants also have been studied in treating domestic wastewater (Ran et al., 2004), municipal wastewater (Greenway and Woolley, 1999; Dalu and Ndamba, 2003) as well as industrial wastewater (Miretzky et al., 2004). Brix (1994) and Reed et al. (1995) have studied the effect of roots of emergent plants on providing oxygen to substrate and bacteria. Another study has been reported by Sasikala et al. (2009) on root oxygen release by emergent plants in vertical flow CWs.

However, the studies on effect of combine system of submerged and floating plants on pollutant removal in CWs are still not adequately reported. Therefore, this study aims to investigate the DO dynamics in CWs with $H$. verticillata (submerged) and $L$. minor (floating). The specific objectives were to examine the effect of depth, distance from the inlet and time of the day on DO concentration and nitrogen removal in CW systems in combination with plants.

\section{MATERIALS AND METHODS}

\section{Wetland units}

A pilot scale study was carried out at University of Peradeniya, Sri Lanka $\left(7^{\circ} 15^{\prime} \mathrm{N} 80^{\circ} 35^{\prime} \mathrm{E}\right)$ to treat secondary treated wastewater (Effluent from a treatment system of septic tank followed by an emergent plant constructed wetland). Four CW units, A, B, C and D were constructed each with the surface area of $3 \times 1 \mathrm{~m}^{2}$ as shown in Fig. 1. The units A and B were constructed with depths 0.3 and $0.6 \mathrm{~m}$, respectively. The unit $\mathrm{C}$ was constructed with two sections, shallow $(0.3 \mathrm{~m})$ water column followed by a deep $(0.6 \mathrm{~m})$ water column. These sections were connected with a pipe. The unit $\mathrm{D}$ was similar to the unit $\mathrm{C}$, but deeper water column was followed by shallow water column. Sand was filled up to $0.1 \mathrm{~m}$ depth at the bottom of each wetland unit.

\section{Planting}

The units $\mathrm{A}$ and $\mathrm{B}$ were planted with $H$. verticillata and $L$. minor with the initial plant density of 100 plants $\mathrm{m}^{-2}$ and $8 \%$ surface coverage, respectively. The first and second sections of the unit $\mathrm{C}$ was planted with $H$. verticillata and $L$. minor, respectively while the unit $\mathrm{D}$ was planted in other way around. The system was fed with tap water for a week to assure the initial plant establishment and to avoid the shock by the wastewater to the plants. Subsequently, secondary treated wastewater was fed to the units at a rate of $3 \mathrm{mLs}^{-1}$ so that the hydraulic retention time of 6 days was achieved.

\section{Dissolved Oxygen measurement}

Dissolved oxygen (DO) was measured when the plants reached the maximum growth (i.e. when $H$. verticillata reached the highest plant density and L. minor grown to provide $100 \%$ coverage). Dissolved oxygen was measured by a DO meter (SATO SHOUJI INC, DO-5509) in six hours intervals $(06.00 \mathrm{~h}, 12.00 \mathrm{~h}$ and $18.00 \mathrm{~h}$ ) during the day at water surface and the depths of $0.2,0.4$ and $0.5 \mathrm{~m}$ from the water surface. This was repeated along the $\mathrm{CW}$ units at $0.5 \mathrm{~m}$ interval from the inlet. Similarly, DO were measured at the water surface and the depths $0.1 \mathrm{~m}$ and $0.2 \mathrm{~m}$ shallow water column with $H$. verticillata from the free water surface. 
Influent and effluent water samples were collected at weekly intervals and measured the total nitrogen (TN) concentration was measured using standard methods (APHA, 1980). Removal efficiency of TN was calculated using the Equation 1.

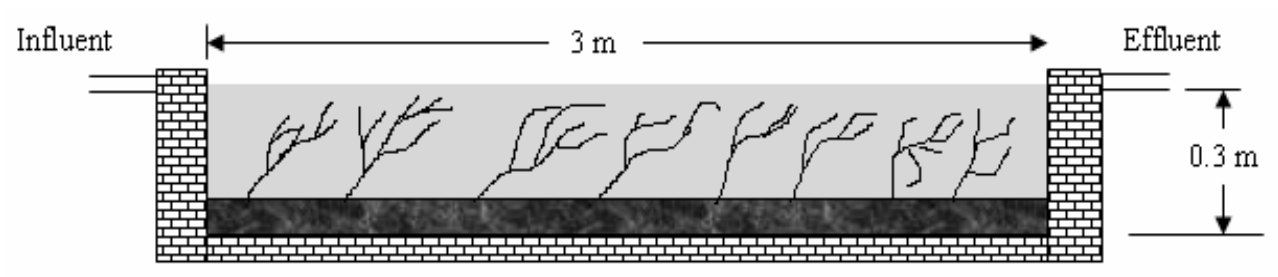

(a)

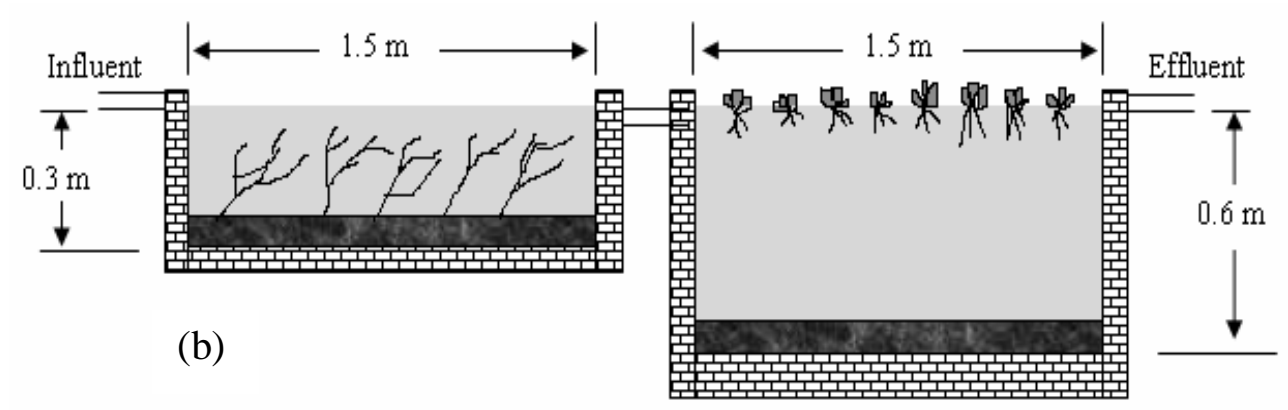

Fig. 1. Schematic diagram of (a) wetland unit A ( $0.3 \mathrm{~m}$ deep; H. verticillata) and B (0.6 m deep: L. minor) (b) wetland unit $\mathrm{C}(0.3$ and $0.6 \mathrm{~m}$ deep) and $\mathrm{D}(0.6$ and $0.3 \mathrm{~m}$ deep)

$$
\begin{gathered}
\eta=\frac{\left(\mathrm{C}_{\text {in }}-\mathrm{C}_{\text {eff }}\right)}{\mathrm{C}_{\text {in }}} \times 100 \\
\eta=\% \text { removalefficiency } \\
\mathrm{C}_{\text {in }}=\text { influentconcentration }\left(\mathrm{mg} \mathrm{L}^{-1}\right) \\
\mathrm{C}_{\text {eff }}=\text { effluentconcentration }\left(\mathrm{mg} \mathrm{L}^{-1}\right)
\end{gathered}
$$

\section{RESULTS AND DISCUSSION}

\section{Effect of plant type on DO concentration}

Figure 2 shows the plant growth variation in unit A and B with time. Sections in C and D with $H$. verticillata and $L$. minor also showed a similar variation in plant growth. $H$. verticillata has reached its maximum growth by 30 days and died due to adverse environmental conditions. However, it has grown again and reached its maximum growth within 30 days. The L. minor took about 75 days to provide a dense mat with $100 \%$ coverage. 


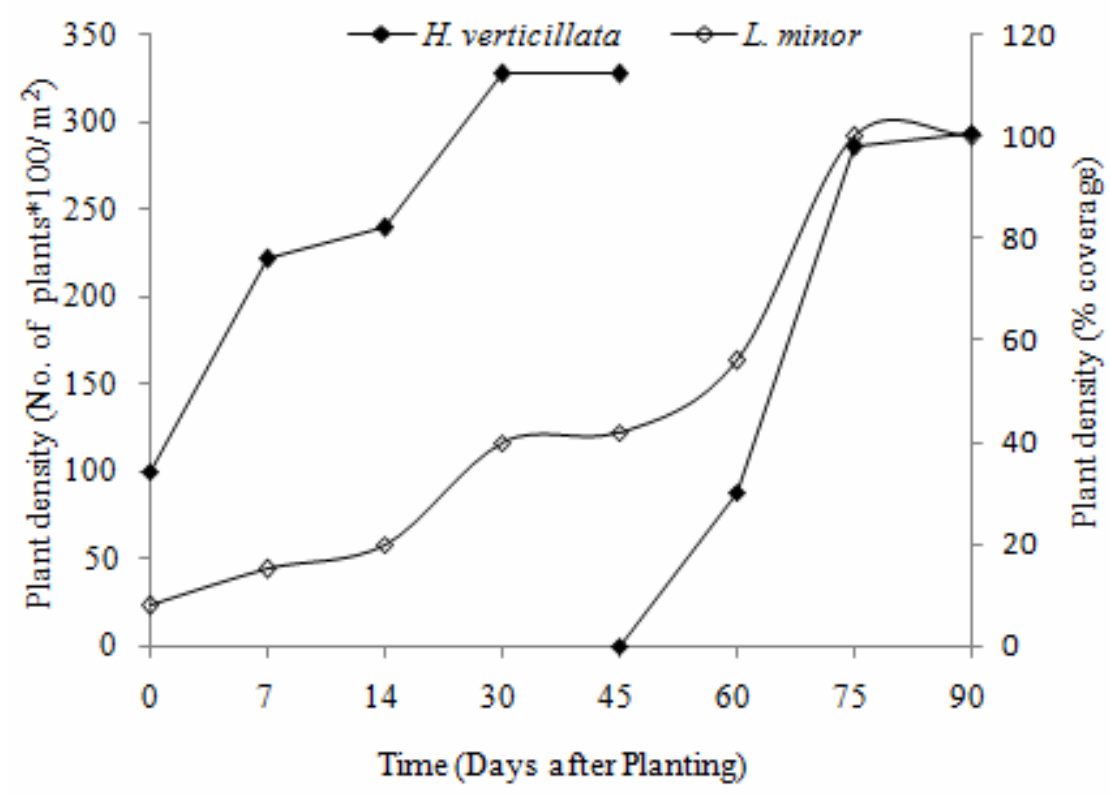

Fig. 2. Plant growth variation with time

Dissolved oxygen concentrations were compared among the $\mathrm{CW}$ units. The DO variation in units $\mathrm{A}$ and $\mathrm{B}$ are shown in Table 1. Figure 3 illustrates the DO variation in units $\mathrm{A}$ and $\mathrm{B}$ at $0.2 \mathrm{~m}$ depth with time. The highest DO concentration was resulted at noon at all depths while the lowest has been resulted before dawn in unit A with $H$. verticillata. A similar result has been reported by Mowjood and Kasubuchi (2002) in ponded water of the paddy field. They also observed the super saturation of DO around $12 \mathrm{~h}$. The maximum DO was $20 \mathrm{mg} \mathrm{L}^{-1}$ at noon and the lowest was $1.4 \mathrm{mg} \mathrm{L}^{-1}$ in the early morning at the depth of $0.1 \mathrm{~m}$ below the water surface in the unit A. In contrast, DO was very low in units with $L$. minor. The DO varied from 0.2 to $1.1 \mathrm{mg} \mathrm{L}^{-1}$ throughout the day in all depths in the unit $\mathrm{B}$.

Table 1. The DO in units A and B at different depths in different times of the day

\begin{tabular}{ccccc}
\hline \multirow{2}{*}{ Time (h) } & \multicolumn{2}{c}{ Wetland A } & \multicolumn{2}{c}{ Wetland B } \\
& Depth $(\mathbf{m})$ & DO $\left(\mathbf{m g ~ L}^{\mathbf{- 1}}\right)$ & Depth $(\mathbf{m})$ & DO $\left(\mathbf{m g ~ L}^{\mathbf{- 1}}\right)$ \\
\hline \multirow{3}{*}{0600} & 0.0 & 1.9 & 0.0 & 0.6 \\
& 0.1 & 1.4 & 0.2 & 0.5 \\
& 0.2 & 1.2 & 0.4 & 0.2 \\
& & & 0.5 & 0.2 \\
1200 & 0.0 & 19.7 & 0.0 & 1.1 \\
& 0.1 & 20.0 & 0.2 & 0.4 \\
& 0.2 & 17.7 & 0.4 & 0.3 \\
& & & 0.5 & 0.2 \\
& 0.0 & 8.4 & 0.0 & 0.5 \\
& 0.1 & 13.5 & 0.2 & 0.3 \\
& 0.2 & 7.5 & 0.4 & 0.3 \\
& & & 0.5 & 0.3 \\
\hline
\end{tabular}




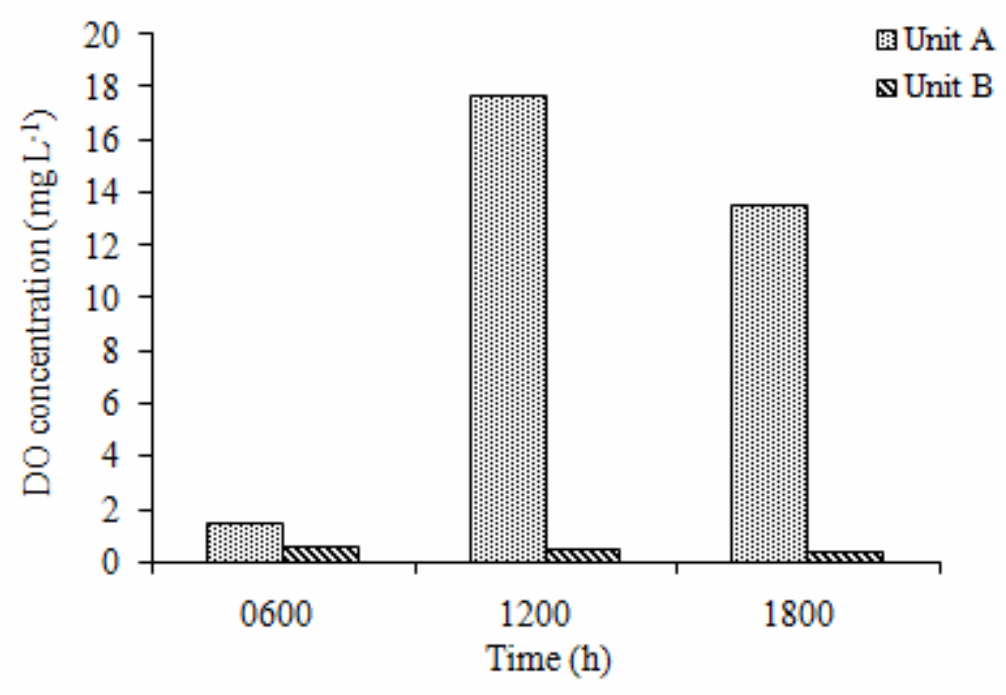

Fig. 3. The variation of DO concentration at $0.2 \mathrm{~m}$ depth in units $A$ and $B$

Due to the submerged nature, oxygen, produced by photosynthesis by $H$. verticillata in the day time increased the DO concentration in the unit A. Oxygen source is not available in the unit B due to the floating nature of $L$. minor. Shading by the abandoned floating plants and shelter the water column from atmospheric oxygen diffusion caused the lower level of DO in the unit B. Nahlik and Mitsch (2006) also observed the same results in similar wetlands studies.

The low DO concentration in early morning may be due to the oxygen consumption by plants (dark respiration) and other organisms present in water.

\section{Effect of depth on DO concentration}

Dissolved oxygen concentration varied with depths and not with the distance from the inlet to the outlet in all the wetland units. This shows that the DO in submerged units is more influenced by one dimensional (vertical) transfer. The DO concentration in the unit A at 0.1 $\mathrm{m}$ depth is higher than the water surface between noon and the evening. The saturated DO concentration at $25{ }^{\circ} \mathrm{C}$ is $8.2 \mathrm{mg} \mathrm{L}^{-1}$ (Whipple and Whipple, 1911). Since the water in the unit A contains DO more than the saturated level, the oxygen transferred from the water to the atmosphere in order to reach equilibrium is referred as deaearation (Lewis and Whitman, 1924). In contrast, in unit B, the DO concentration at the surface is higher than the sub surface. This may be due to reaeration, the transfer of oxygen from atmosphere into water since DO is lower than the saturated level.

\section{Nitrogen removal from wastewater}

Nitrogen removal capacity of each unit was also different as a result of variation in DO concentrations in CWs. Total nitrogen (dissolved inorganic nitrogen, particulate organic nitrogen and dissolved organic nitrogen) is an important indicator of nutrient loading to a water course and the removal is affected by the DO concentration. Table 2 shows the TN 
concentration in effluent and removal efficiencies for $70 \mathrm{mg} \mathrm{L}^{-1}$ influent concentration. Accordingly, higher TN removal has resulted from the units A, C and D compared to unit B. Anoxic and oxic order in unit $\mathrm{D}$ resulted $75 \%$ of nitrogen removal.

Table 2. Total nitrogen removal efficiencies imparted by wetland units

\begin{tabular}{ccc}
\hline Wetland unit & Effluent concentration $\left(\mathbf{m g ~ L}^{\mathbf{- 1}}\right)$ & Removal efficiency (\%) \\
\hline A & 28 & 60 \\
B & 49 & 30 \\
C & 26 & 63 \\
D & 19 & 75 \\
\hline
\end{tabular}

\section{CONCLUSIONS}

The DO concentration was varied significantly with the type of plant, depth from the water surface and the time of the day. CW units with submerged plant showed a greater oxygen level than units with floating plant units. DO concentration ranged from 1.2 to $20 \mathrm{mg} \mathrm{L}^{-1}$ in submerged wetlands while it was from 0.2 to $1.1 \mathrm{mg} \mathrm{L}^{-1}$ in floating plants system. Thus, floating plants creates an anoxic condition in submerged water bodies. Higher DO was observed during noon in submerged plant wetlands at all depths. However, DO did not vary with distance from the inlet to the outlet. Deaeration process occurred in the unit A due to supersaturated level of DO. Lack of solar radiation and photosynthesis and low reaeration caused low level of DO in the unit B. Therefore, oxic and anoxic conditions can be obtained using submerged and floating plants in constructed wetlands.

The highest nitrogen removal was achieved from the combined system of anoxic and oxic conditions that is L. minor plants followed by $H$. verticillata system (unit D). The lowest removal efficiency was shown in the unit B where only the anoxic conditions prevailed. The integration of submerged and floating plants are important not only as cost effective methods of maintaining DO as required but also as it plays an important role in removing pollutants by plant uptake.

\section{REFERENCES}

APHA, AWWA, WPCF. (1980). Standard Methods for the Examination of Water and Wastewater. $15^{\text {th }}$ ed. American Public Health Association. Washington.

Brix, H. (1994). Use of constructed wetlands in water pollution control: historical development, present status and future perspectives. Water Sci. Technol. 30: 209-223.

Chang, H., Xiao-c, Y., Yun-ying, F., Pu Pei-min, Zhen-kui, L. I. and Zed, R. (2006). In-Situ nitrogen Removal from the eutrophic water by microbial-plant integrated system. J. Zhejiang Univ. Sci. B. 7(7): 521-531. 
Dalu, J.M. and Ndamba, J. (2003). Lemna based wastewater stabilization ponds for wastewater treatment (a low cost technology for small urban areas in Zimbabwe). Physics and Chemistry of the Earth. 28: 1147-1160.

Eighmy, T.T. and Bishop, P.L. (1989). Distrbution and role of bacterial nitrifying populations in nitrogen removal in aquatic treatment systems. Wat. Res. 23(8): 947-955.

Greenway, M. and Woolley, A. (1999). Constructed wetlands in Queensland: performance efficiency and nutrient bioaccumulation. Ecolo. Eng.12: 39-55.

Imfeld, G., Braeckevelt, M., Kuschk, P. and Richnow, H.H. (2009). Monitoring and assessing processes of organic chemicals removal in constructed wetlands. Chemosphere. 74: 349-362.

James, C.S., Eaton, J.W. and Hardwick, K. (1999). Competition between three submerged macrophytes, Elodea canadensis Michx, Elodea nuttallii (Planch.) St John and Lagarosiphon major (Ridl.) Moss. Hydrobiologia. 415: 35-40.

Kanabkaew, T. and Puetpaiboon, U. (2004). Aquatic plants for domestic wastewater treatment: Lotus (Nelumbo nucifera) and Hydrilla (Hydrilla verticillata) systems. Songlanakarin. J. Sci. and Tech. 26(5): 749-756.

Karjalainen, H., Stefansdottir, G., Touuminen, L. and Kairesalo, T. (2001). Do submerged plants enhance microbial activity in sediments?. Aqua. Bot. 69: 1-13.

Lewis, W.K. and Whitman, W.G. (1924). Principles of gas absorption. Indus. trial and Eng. Chem. 16(12): 1215-1221.

Miretzky, P., Saralegui, A. and Cirelli, A.F. (2004). Aquatic macrophytes potential for the simultaneous removal of heavy metals (Buenos Aires, Argentina). Chemosphere. 57: 9971005.

Mowjood, M.I.M. and Kasubuchi, T. (1998). Dynamics of dissolved oxygen (DO) in ponded water of a paddy field. Soil Sci. and Plant Nutr. 44: 405-413

Mowjood, M.I.M. and Kasubuchi, T. (2002). Effect of convection on the exchange coefficient of oxygen and estimation of net production rate of oxygen in ponded water of a paddy field. Soil Sci. and Plant Nutr. 48: 673-678.

Nahlik, A.M. and Mitsch, W.J. (2006). Tropical treatment wetlands dominated by free floating macrophytes for water quality improvement in Costa Rica. Ecolo. Eng. 28: 246-257.

Ozimek, T., van Donk, E. and Gulati, R.D. (1993). Growth and nutrient uptake by two species of Elodea in experimental conditions and Their Role in Nutrient Accumulation in a Macrophyte- Dominated Lake. Hydrobiologia. 251: 13-18.

Ran, N., Agami, M. and Oron, G. (2004). A pilot study of constructed wetlands using duckweed (Lemna Gibba L.) for treatment of domestic primary effluent in Israel. Water Res. 38: $2241-2248$. 
Reed, S., Middlebrooks, E. and Crites, R. (1995). Natural Systems for Waste Management and Treatment. McGraw Hill.

Sasikala, S., Tanaka, N., Wah, H.S.Y.W. and Jinadasa, K.B.S.N. (2009). Effects of water level fluctuation on radial oxygen loss, root porosity and nitrogen removal in subsurface vertical flow wetland mesocosms. Ecolo. Eng. 35: 410-417.

Tanner, C.C., Kadlec, R.H., Gibbs, M.M., Sukias, J.P.S. and Nguyen, M.L. (2002). Nitrogen processing gradients in subsurface-flow treatment wetlands - influence of wastewater characteristics. Ecolo. Engi. 18: 499-520.

Whipple, G.C. and Whipple, M.C. (1911). Solubility in sea water. J. Am. Chem. Soc. 33:362-368. 